\title{
Social and Legal Technologies in the System of Legal Policy
}

\author{
Maxim Valer'evich Voronin ${ }^{1} \&$ Igor Vladimirovich Przhilenskiy ${ }^{2}$ \\ ${ }^{1}$ Kazan Federal University, Trainee Researcher at the Law Faculty of the Moscow State University named after \\ M. V. Lomonosov, Russia \\ ${ }^{2}$ North-Caucasus Federal University, Russia \\ Correspondence: Maxim Valer'evich Voronin, Kazan Federal University, Russia. E-mail: \\ maksim.v.voronin@mail.ru
}

Received: June 9, 2019

Accepted: August 25, $2019 \quad$ Online Published: August 31, 2019

doi:10.5539/jpl.v12n5p48

URL: https://doi.org/10.5539/jpl.v12n5p48

\begin{abstract}
The article considers the problem of implementing of legal policy as a social technology. The authors compare the concepts of social and legal technology as a set of elements in achieving the goal, and also consider systematicity as the main property of these technologies. The systematic approach is presented both at the decision-making level and at the stages of its legislative execution and practical application in the process of implementing of legal norms.

The implementation of legal policy led to the dynamics of legislative changes in recent years. Various state institutions have been reformed and actually reorganized to work on the basis of new principles. Moreover, the reforms of recent years are determined not only and not so much by objective ideological transformations associated with the transition to democracy, the implementation of international law, but also by a change in the technological paradigm of management and implementation of political processes. The actions of the executive and legislative branches, as well as the entire process of legal proceedings in courts of various levels, are considered in the article as unique social technologies, all of which are systemic in nature. The authors conclude that the consistency of power, social and legal technologies serves as a vehicle for political legal strategy, and also allows you to express the functionality of the main legal institutions.
\end{abstract}

Keywords: consistency, legal policy, social technology, state, legal proceedings

\section{Introduction}

Systematicity as the integrity of various elements is traditionally present in any norm-setting and law enforcement practice as an integral attribute of the goal-setting of such an activity. Consistency is also a basic property of any legislation - both individual acts and branches of law.

But speaking of systemicity as a property and attribute, we will try to look at its nature through the functionality of this phenomenon. Here you can ask a number of questions. Why is law organized and structured as a system, which in turn also consists of subsystems and so on? And why do legal norms and customs practically do not exist on their own, just as a set of separate prescriptions and rules that are not united by a single concept and do not form an interconnected structure?

It would seem that, at first glance, the answers are obvious: systematization of law is the most convenient and accurate way of codification, combining norms into acts, acts - in the industry, industries - into national legal systems. But at the same time, systematicity is an instrument in the hands of the actor who creates and uses the law for his own purposes, namely, the state. In one form or another, depending on the prevailing features, it is the state that develops and applies regulatory legal acts. Judicial activity is also one of the parties to this process. And precisely because of the unity and consistency of state policy in any given time period, any specific legal system is being formed. Therefore, we can conclude that legal norms are systematized, and systems are accordingly formed on the basis of the strategic and political tasks facing the state. That is why, while discussing legal policy in a particular branch of law, scientists always turn to the comprehension of global, strategic goals facing the state. Moreover, this rule is, perhaps, universal for states with any type of device of power, forms of government: these can be democracies and dictatorships, republics and monarchies. The principle of the instrumental nature of law and the endowment of legal institutions with strategic objectives cannot be realized without a systematic approach to the creation, formation and application of law. 


\section{Methods}

I would like to note the use of the systematic method in the development and implementation of legal policy strategies in the context of the technological approach, where systematicity acts as a social, and in a narrower sense, legal technology. The methodological basis for the analysis of the problems of implementing social technologies along with the provisions of the general theory of cognition was also the logical, systemic and comparative legal approaches.

\section{Results and Discussion}

At the junction of the legal and humanitarian sciences, the issue of understanding various processes through the prism of social technologies, which in essence create a new content of the concepts of administration, management, social engineering, is currently being updated. At the same time, law as a whole and its individual branches are also understood by scientists as technologies, and this approach allows us to identify the most effective ways to solve problems in the process of creating and implementing legal norms at different stages. "The Soviet jurisprudence bound the measure of law only with the state mediation of public relations. In modern Russia, the paradigm of legal measure verification is being changed by science and practice. The Russian jurisprudence is objectively transformed under the influence of global trends in the development of the legal map of the world. "Such trends include convergence of legal systems of our time and competition of law and order."

The technological approach to rulemaking or law enforcement makes it necessary to build certain chains similar to algorithms in which any action can be evaluated as an element of a single system for performing a given function. Moreover, the term "legal technology" is often used by lawyers in a meaning close to the established concept of "legal technology", that is, in an applied and somewhat utilitarian sense. As noted by M.A. Kostenko, the term "legal technique" is very controversial and inaccurate, but rather used as a tribute to the legal tradition. In this vein, legal technology is considered as a system of methods, procedures and techniques aimed at converting relevant social information into updating normative legal acts and techniques for their application.

However, in a broader sense, legal technology as an element of social technologies can appear to be an equivalent concept to law as such, because law, by its appointment in society, has regulatory functions and is a technology for implementing a particular state policy. It is suggested that a number of legal institutes are special social technologies that serve not only in the formation of law, but also for solving problems such as correlating individual life cases with a general legal norm, i.e. direct enforcement. On the example of criminal proceedings L.A. Voskobitova considers social technology as a set of procedures, methods and techniques, essentially acting as a cognitive process aimed "first to establish the factual basis of the case, then to establish the legal basis of the case and, finally, to adopt an authoritative sub-normative act that implements individual sub-normative regulation of the behavior of subjects of the rights".

If we consider legal proceedings as a special social technology as an example of a criminal process, we will see that it is aimed at achieving certain goals of the criminal policy of the state as a whole. But also the criminal process in each case solves the applied task of considering a criminal case, that is, investigating a crime, bringing the perpetrator to justice, restoring of social justice and, when possible, making amends to the victim, and possible compensation for the damage that was inflicted by crime. The process acts as a technology, i.e. a certain set of receptions and actions of competent persons acting within the framework of powers defined by law.

In the same way, along with the procedural norms, the substantive law norms are also being implemented within the framework of the judicial technology: criminal, administrative, civil, arbitration, etc. They are applied by officials or judges within the framework of the rules for their application described in the laws themselves. On the example of the same criminal proceedings, we can say that in substantive law the law is traditionally divided into two parts - general and special. Within the framework of the methodology of the technological approach, it can be said that the general part by its purpose describes the technology of application of the norms proper, and the special part directly represents an exhaustive list of criminal offenses and sanctions for them.

So, to illustrate the thesis that the norms of the General part of the Criminal Code are the basis of the technology for applying criminal law, it is enough to cite a number of institutions in this section. The General Part provides basic concepts used in criminal law, such as a crime, its object and subject, types and forms of guilt, the concept and significance of crimes committed intentionally or through negligence. Here, the legislator also discloses, in sufficient detail and technologically, the methods and methods of sentencing in certain situations when there are mitigating or aggravating circumstances in relation to the defendant, or it is a sentence for several different crimes. All of the above institutions without a doubt meet the criteria of technology, where the legislator gives the law enforcer certain tools, clearly and unequivocally explains the limits of discretion and the algorithms of action in qualifying crimes, imposing sentences or, conversely, excluding criminal liability in a person's actions, if this is expressly provided for by law. 
The examples given by us indicate that the legislator outlines for those officials who will apply the law a rather strict framework, creating not just restrictions, but also setting certain algorithms for their behavior. According to these algorithms, judges, investigators, bailiffs, notaries, various public servants are forced to literally, often without the right to their own discretion, perform certain functions.

However, we can guess why the state, when it seems possible, limits as much as possible the arbitrariness of its own officials, trying to regulate their activities as much as possible, and to subordinate as much of their actions as possible to the norms. Surely this makes it possible to create a uniform and controlled environment for managing society, establish the priority of norms over any legal relations and minimize the possibility of independent regulation by society of those areas over which the state is vitally important for its political purposes.

In general, specific legal systems are social technologies that govern the industry of individual legal relations. It is the subordination of their single system of principles, industry characteristics that makes their elements not only interconnected, but also complementing each other. However, the question of legality as legitimacy by tradition does not arise. "A national legal tradition could be seen as originating in the creation of a particular state, and since same states are of recent origin, their legal traditions could be seen as recent or new."

Systematicity allows you to build a single chain of relationships between norms, guidelines and prescriptions so that they form a single code of rules, a specific algorithm, ideally devoid of gaps and conflicts. At the same time, those conflicts of law that nevertheless occur within its branches, or in case of possible competition of legal norms from different areas of regulation, remain exceptions and are in the nature of technical errors that should be identified in the process of law enforcement and somehow resolved at the level of competent persons, and after and in law.

Systematicity as a technology of law is both a property and a rule of approach to a particular task that this technology is called upon to implement. The systematization of various regulatory institutions at all levels of legislation contributes to a uniform and consistent understanding of the legal policy of the state in a particular area. So, using the example of the norms of the Special Part of the Criminal Code of the Russian Federation, creating the substantive law, the legislator brings the various elements of crimes in accordance not with one, but with several systems connected with their severity, object, and other elements. For example, all sections and chapters of the General part are built on the basis of the object on which the unlawful act encroaches, from the generic (sections) to the species (chapters) and direct (articles or parts thereof). Moreover, the legislator builds the crimes themselves for a certain differentiation into a separate system, namely, divides them into categories depending on the severity. This classification is also interconnected with the size of the sanction, namely, the terms of imprisonment provided as the main punishment for the majority of crimes in the Code.

If, after the adoption of the text of the law, changes are made to it, which is almost inevitable due to objective reasons, and in today's legal realities it has even become a problem, then these changes should be incorporated into the systems that have already been created, and the unity of their elements should be taken into account. Relatively speaking, if the legislator suddenly abruptly changes the sanction of a crime towards mitigation, or, on the contrary, unjustified aggravation, then this should be consistent with sanctions for similar elements of the crime, or compositions with a related object. Otherwise, this can lead to a bias in law enforcement and reduce the effectiveness of sanctions for other crimes, which will be more profitable to commit from the point of view of the criminal. Thus, the effectiveness of the entire repressive effect of criminal or other legislation will suffer in general.

Also, examples of a systematic approach to rule-making can serve as a system of principles, both general legal and cross-industry and industry, which are also built on the basis of mutual complementarity and dependence. In the procedural branches of law, the legislator builds a systematic approach to creating a chain of stages of justice, authorities and verification proceedings. The types of evidence that the courts of the Russian Federation have the right to consider reliable, acceptable and permissible are systematized, unified systems of grounds for the cancellation or amendment of judicial decisions of lower courts by higher ones are formed.

Systematic rulemaking is also expressed in the unity and structurality of the conceptual apparatus of law, which arises from the everyday experience of social relations through the conceptualization of everyday concepts. According to D.V. Vlasov, "Law is not just a mirror image of the system of public relations, its ontological status is connected with the system of basic values that exist in the public mind."

Правовые принципы и понятия постоянно подвергаются переоценке в силу динамики общественных изменений. Different layers of values can be transformed at different speeds depending on their functions and the ratio of traditionalist and innovative trends in politics, culture and morality. The development of new traditions, their entry into conflict with established social canons, layering and, often, the emergence of hybrid forms of social norms can be observed on the example of not only Russian, but also any other society. For example, after the era of liberalization and the introduction of innovative forms of social life, reactions almost inevitably occur, which are 
expressed in a critical reappraisal by both society and the politics of drastic changes. At such moments, traditionalist sentiments intensify, the ideas of conservatism take over, which can also decline at some point.

These waves inevitably entail the revision and "rewriting" of legislation, the addition of it with some new norms, or, on the contrary, the removal of unpopular and ineffective provisions. As noted by A.N. Mironov, "the legal sphere of society, in need of transformation, acts as an object of legal policy." In his opinion, legal technology can be used, at least in such forms of implementation of legal policy as lawmaking and law enforcement. [6,120] At the same time, consistency as a property of legal strategy is called upon to ensure the integrity and continuity of this policy. Then changes in various layers of the law will not entail a chaotic disintegration of the entire structure of certain branches of law, and the transition will be more evolutionary in nature. "There are many circumstances in which physical systems are more effective in controlling human behavior than legal systems. For example, a few decades ago, the theft of social security checks from mailboxes was a major problem. The system might have responded with more laws, more law enforcement, and harsher penalties. Instead, it responded by directly depositing the social security check in the payee's bank account, which solved the problem. Systems analysis can assist in identifying other areas in which effective physical systems can replace ineffective laws.

\section{Summary}

As a result, we conclude that consistency is an essential property of legal and social technologies. An important thesis is that the term "legal technology" can be used not only as a synonym for legal technology, but also applied not only to rule-making or legislative activities, but also to law enforcement. The technology itself, i.e. a specific set of tools and methods to achieve the task, is inherent not only to the rules of law, but also to the mechanism of action of law enforcement. Thus, we are talking not only about law-making technology, but also about law as a social technology, which is an instruction and algorithm for investigators and lawyers, judges and prosecutors, officials and notaries, any subjects of legal relations to which the rule of law applies.

\section{Conclusions}

The law describes a possible sequence of actions of process participants, contains a conceptual framework and prescribes behavioral patterns to subjects, allowing or restricting them in various situations. The norms describe general algorithms of actions that should cover individual, unique situations, and thus the norm universalizes various cases. The subject of the application of the law should be able to choose and apply the general rule to a specific life situation on a number of grounds, which should also be used directly or indirectly in legislation.

Then the law enforcement practice will, to the extent necessary, comply with the request placed on these institutions by the legislator. Moreover, the effectiveness of legal regulation as a social technology allows you to remove the contradictions that daily arise between various entities: between the government and society, between society and the individual, between various individuals, between the state and the individual, between various state structures, civil society structures, whose functionality is also often may conflict. Often, conflicts in government structures, between different groups of society, or between specific individuals and society, arise precisely because of a violation of the systematic approach to the implementation of legal policy, i.e. in conditions when the law as a whole and such state institutions as the court, police, legal profession, nominally preserved, lose their real regulatory functions. In this case, it can be stated that in general, social technology ceases to effectively fulfill its function.

Thus, systems in the legal space are called upon to unite various elements in such relationships that will build legal norms both in hierarchical structures and in meaningful horizontal subsystems. The consistency of the described technologies acts as a conductor of the political legal strategy, and allows you to reflect the functionality of the main legal institutions in the necessary relationship.

\section{Acknowledgements}

The work is performed according to the Russian Government Program of Competitive Growth of Kazan Federal University.

\section{References}

Glenn, P. (2000). Legal Traditions of the World. Sustainable Diversity in Law. Oxford University Press.

Hegel, H. (2001). Philosophy of Right. Kitchener. Ontario.

Kostenko, M. A. (2009). Legal technology as a way to implement the law-making policy of the state. Izvestiya YuFU. Engineering sciences, (3).

LoPucki Lynn, M. (1997). Systems Approach to Law. Cornell Law Review, 82(3), 480-522.

Mironov, A. N. (n.d.). Legal technology as a means of implementing of legal policy. Bulletin of the Vladimir Law Institute.

Vlasov, D. V. (2009). Consistency of the conceptual apparatus of law. Scientific notes of the Russian State Social University, (1). 
Voronin, M. V., \& Zakharova, M. V. (2017). The Problem of the Exercise of Law in Russia and France: National and International Aspects. Quid: Investigación, Ciencia y Tecnología, (1), 1642-1646.

Voskobitova, L. A., \& Przhilensky, V. I. (n.d.). Social technologies and legal knowledge: monograph. Norma: INFRA-M.

Zakharova, M. V., \& Voronin, M. V. (2016). Comparative Law: Postclassical Epoch. The Turkish Online Journal of Design Art and Communication, 6, 2480-2484.

Zakharova, M., \& Przhilenskiy, V. (2017). Two Portraits on the Background of the Revolution: Pitirim Sorokin $\begin{array}{llll}\text { and Mikhail Reisner. Russian Law Journal, } & \text { 193-212. }\end{array}$ https://doi.org/10.17589/2309-8678-2017-5-4-193-212

\section{Copyrights}

Copyright for this article is retained by the author(s), with first publication rights granted to the journal.

This is an open-access article distributed under the terms and conditions of the Creative Commons Attribution license (http://creativecommons.org/licenses/by/4.0/). 